\title{
Meta-Analysis: The Association between Social Support and Postpartum Depression
}

\author{
Ardiani $^{1}$, RB. Soemanto'), Bhisma Murti1) \\ 1)Masters Program in Public Health, Universitas Sebelas Maret \\ ${ }^{2)}$ Faculty of Social and Political Sciences, Universitas Sebelas Maret
}

\section{ABSTRACT}

Background: Postpartum depression is a mood disorder that occurs in the first year after childbirth, which affects mothers, babies and their families. The prevalence of postpartum depression is estimated to be $10-15 \%$ worldwide. Postpartum women who have weak social support are at risk for postpartum depression. This study aimd to estimate the strength of the relationship between social support and postpartum depression based on the results of previous similar studies.

Subjects and Method: This research is a systematic review and meta-analysis. Meta analysis is carried out by systematically reviewing articles published from 2010 to 2020 from the Pubmed, Google Scholar, Science Direct, and Spinger Link databases using search keywords, namely "social support" OR "family support" OR "partner support" AND" postpartum depression "OR" postnatal depression "AND" cross sectional "AND" multivariate. Article searches were carried out using PICO. The study population was postpartum women, intervention/ exposure was weak social support with comparison was strong social support and the outcome was postpartum depression. The search for articles was carried out for one month. The articles included in this study were full text articles with cross sectional design. Articles were reviewed using the PRISMA flow diagram guidelines. Articles analyzed using Revman $5 \cdot 3$ Software.

Results: 12 articles were reviewed in this study. This study shows that weak social support increased the risk of postpartum depression $(\mathrm{aOR}=2.64 ; 95 \% \mathrm{CI}: 2.08-3.35 ; \mathrm{p}$ $<0.001)$.

Conclusion: Weak social support increases the risk of postpartum depression.

Conclusion: Weak social support increases the risk of postpartum depression.

Keywords: social support, postpartum depression

\section{Correspondence:}

Ardiani. Masters Program in Public Health. Universitas Sebelas Maret, Jl. Ir. Sutami 36A, Surakarta 57126, Central Java. Email: dhiniardiani@gmail.com. Telepon: 085337742831.

\section{Cite this as:}

Ardiani, Soemanto RB, Murti B (2020). Meta-Analysis: The Association between Social Support and Postpartum Depression. J Matern Child Health. 05(06): 641-650. https://doi.org/10.26911/thejmch.2020.05.06.04.

\section{BACKGROUND}

Postpartum depression is one of the main problems and not only affects the health of mothers and babies (Tambag et al., 2018) but also their partners and the whole family (Ozbasaranet al., 2011) and also society (Vaeziet al., 2018). The postpartum period causes emotional stress to new mothers, even more troublesome when accompanied by intense physical changes. There are many factors that influence the success of the transition to parenting during the postpartum period, one of which is the support factor from family and friends. Many postpartum mothers experience feelings of let down after giving birth due to the 
seriousness of their experience at birth and doubts about their ability to cope effectively in raising a child (Bahiyatun, 2010).

Postpartum depression usually occurs in weeks 2 to 6 months after delivery (Fedora, 2019). The prevalence of postpartum depression is estimated to be around 10-15\% worldwide (Vaeziet al., 2018). In developing countries this figure is even higher at around $19 \%$. In Asia, the incidence of postpartum depression is quite high and varies widely, namely between 26$85 \%$ of postpartum women (Fedora, 2019). Two recent systematic reviews and metaanalyzes show that although the incidence varies by country, the global prevalence of postpartum depression is around $17 \%$ and the incidence is $12 \%$ (Shorey et al in Gomez, 2020).

Social support can be described as all moral and material support including assisting in child care, homework and emotional support provided by those close to mothers in general in stressful situations (Sahinet al in Tambag, 2018). It is important for women to get social support during childbirth and postpartum in relation to the health of both mother and baby. Social support gives a person a feeling of selfworth, psychological well-being, and allows them to access resources during stressful and transitional times in life (Tani and Castagna, 2017).

Although the risk factors for postpartum depression are considered multifactorial, the current literature has consistently identified the important role of social support in the incidence of postpartum depression. Many studies have shown that lack of social support is a risk factor for postpartum depression (Yagmur and Ulukoca, 2010). Based on the above background, there have been many studies examining the relationship between social support and postpartum depression, so conducting a systematic review and metaanalysis is very important to do by combining several relevant studies related to social support and postpartum depression.

\section{SUBJECTS AND METHOD \\ 1. Study Design}

This was a systematic review and meta-analysis. Meta analysis is carried out by systematically reviewing articles published from 2010 to 2020 from the Pubmed, GoogleScholar, Science Direct, and Spinger Link databases using search keywords, namely "social support" OR "family support" OR "partner support" AND "postpartum. Depression "OR" postnatal depression "AND" cross sectional "AND" multivariate.

\section{Population and Sample}

The study population was postpartum women. Intervention/exposure is weak social support by comparison is strong social support. The outcome was postpartum depression.

\section{Inclusion Criteria}

The inclusion criteria in this study are primary research conducted around the world. The research subjects were postpartum women. The articles are published from 2010 to 2020 . The research design is cross sectional. The articles are in English, and the analysis is multivariate (logistic regression).

\section{Exclusion Criteria}

The exclusion criteria were articles that were not full text and published in Arabic, Chinese, and French, RCT, Cohort and Case-control research designs.

\section{Operational Definition of Variables}

Postpartum depression is depression that occurs after childbirth with symptoms including changes in sleep and diet patterns, fatigue, sadness, crying, anxiety and feelings of guilt related to the ability to care for the baby. The instrument used was a questionnaire. Social support is support 
Ardiani et al./ The Association between Social Support and Postpartum Depression

or assistance obtained from others, in the form of emotional support, information, instrumentals and assessments. The instrument used was a questionnaire.

\section{Data Analysis}

Data processing is done with Revman5.3 Software. The variations between each study determine the analytical model that will be used to conclude the final metaanalysis results.

\section{RESULTS}

Search for articles from journal databases, namely Pubmed, Google Scholar, Science Direct, and Spinger Link can be seen in Figure 1:
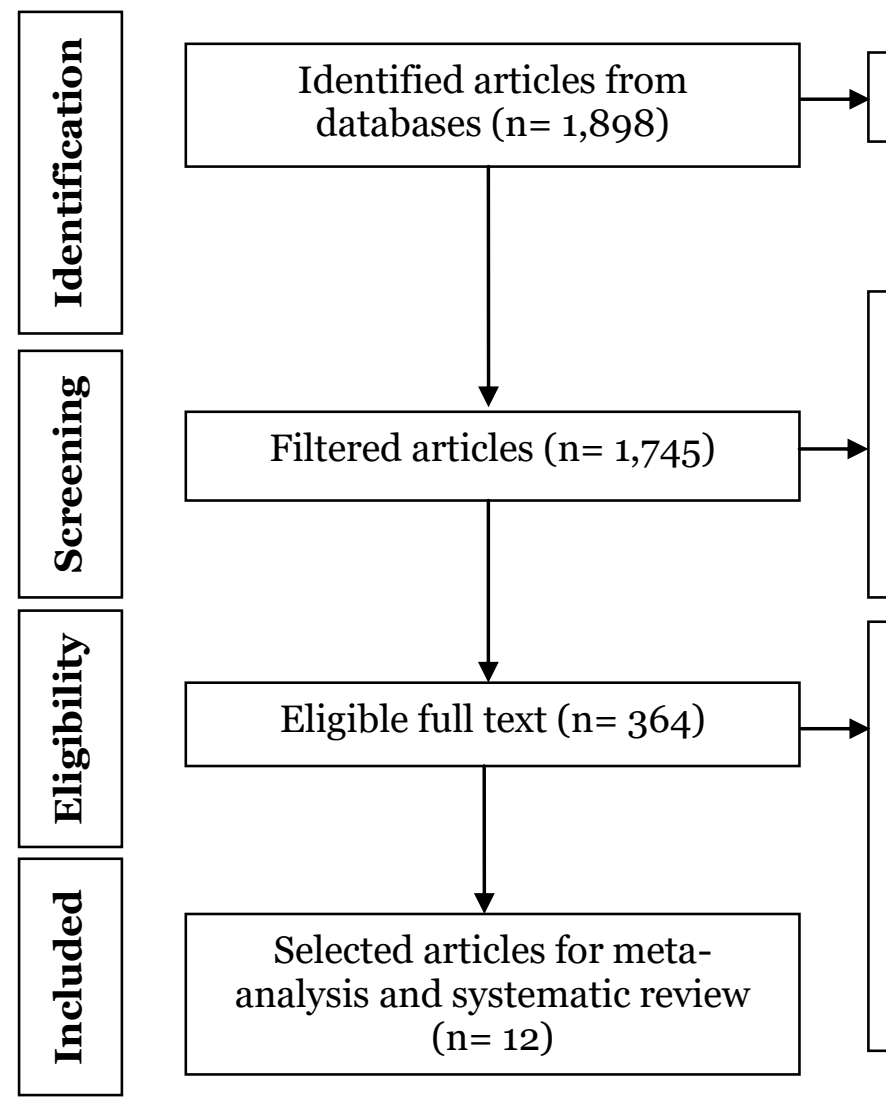

Deleting data duplication $(n=153)$

Drop the articles $(n=8,591)$

1. Irrelevant articles $(n=8,000)$

2. Non RCT $(n=259)$

3. Not in English $(n=98)$

4. Non full text $(n=34)$

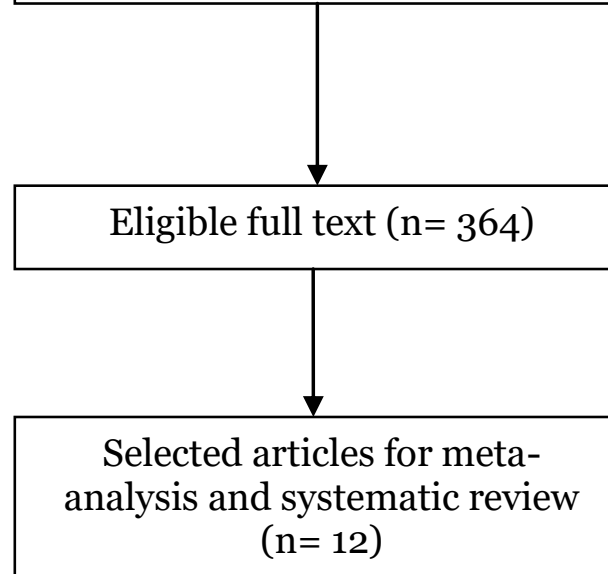

Drop full text with any reason $(n=352)$

1. Non cross-sectional study $(n=115)$

2. Measurement tool was not EPDS $(n=47)$

3. Data analysis was not logistic regression $(n=50)$

4. Did not report aOR $(n=134)$

5. Study with no comparison $(n=6)$

\section{Figure 1. Flow chart of the review process}

\section{a. Social Support and Postpartum Depression}

A total of 12 articles were included as a source for meta-analysis of the relationship between social support and postpartum depression. 
Table 1. Descriptions of the primary studies included in the meta-analysis.

\begin{tabular}{|c|c|c|c|c|c|c|c|}
\hline $\begin{array}{l}\text { Author } \\
\text { (Year) }\end{array}$ & Country & $\begin{array}{l}\text { Study } \\
\text { Design }\end{array}$ & Sample & $\mathbf{P}$ & $\mathbf{I}$ & $\mathbf{C}$ & $\mathbf{O}$ \\
\hline $\begin{array}{l}\text { Bener, et al } \\
(2012)\end{array}$ & Qatar & $\begin{array}{l}\text { Cross } \\
\text { sectional }\end{array}$ & 1.379 & $\begin{array}{l}\text { Postpartum } \\
\text { mother }\end{array}$ & $\begin{array}{l}\text { Family income }<1370 \text { US } \$ \text {, } \\
\text { premature baby, weak family } \\
\text { support *, dissatisfaction in } \\
\text { married life, poor marital } \\
\text { relationships. }\end{array}$ & $\begin{array}{l}\text { Family income }>4109 \text { US } \$ \text {, normal } \\
\text { baby, good family support *, satisfaction } \\
\text { in married life, good marital relationship. }\end{array}$ & $\begin{array}{l}\text { Postpartum } \\
\text { Depression }\end{array}$ \\
\hline $\begin{array}{l}\text { Xiong, et al } \\
(2018)\end{array}$ & China & $\begin{array}{l}\text { Cross } \\
\text { sectional }\end{array}$ & 468 & $\begin{array}{l}\text { Postpartum } \\
\text { mother }\end{array}$ & $\begin{array}{l}\text { Unplanned pregnancy, poor } \\
\text { relationship with mother-in- } \\
\text { law, weak family support *, } \\
\text { parity } 1 .\end{array}$ & $\begin{array}{l}\text { Pregnancy planned, good relationship } \\
\text { with mother-in-law, }\end{array}$ & $\begin{array}{l}\text { Postpartum } \\
\text { Depression }\end{array}$ \\
\hline $\begin{array}{l}\text { Zeadna, et } \\
\text { al (2015) }\end{array}$ & Israel & $\begin{array}{l}\text { Cross } \\
\text { sectional }\end{array}$ & 564 & $\begin{array}{l}\text { Postpartum } \\
\text { mother }\end{array}$ & $\begin{array}{l}\text { Sick baby, history of emo- } \\
\text { tional problems, weak hus- } \\
\text { band support *, stressful } \\
\text { events in a year, low educa- } \\
\text { tion level (<0-9 yrs), percep- } \\
\text { tion of income below average, } \\
\text { unplanned pregnancy, } \\
\text { parity }>2 \text {. }\end{array}$ & Receive family support ${ }^{*}$, parity $>1$ & $\begin{array}{l}\text { Postpartum } \\
\text { Depression }\end{array}$ \\
\hline $\begin{array}{l}\text { Ahmad, et } \\
\text { al (2017) }\end{array}$ & Malaysia & $\begin{array}{l}\text { Cross } \\
\text { sectional }\end{array}$ & $5 \cdot 727$ & $\begin{array}{l}\text { Postpartum } \\
\text { mother }\end{array}$ & $\begin{array}{l}\text { IPV exposure, unplanned } \\
\text { pregnancy, weak family } \\
\text { support *, partner alcohol } \\
\text { use, low income }(<1500 \mathrm{RM})\end{array}$ & $\begin{array}{l}\text { Infants who are not sick, have no history } \\
\text { of emotional problems, good husband } \\
\text { support *, have no stressful events in a } \\
\text { year, education level ( }>10 \text { yrs), } \\
\text { perception of above average income, } \\
\text { planned pregnancy, parity } 1 .\end{array}$ & $\begin{array}{l}\text { Postpartum } \\
\text { Depression }\end{array}$ \\
\hline $\begin{array}{l}\text { Nasr, et al } \\
(2020)\end{array}$ & $\begin{array}{l}\text { Saudi } \\
\text { Arabia }\end{array}$ & $\begin{array}{l}\text { Cross } \\
\text { sectional }\end{array}$ & 174 & $\begin{array}{l}\text { Postpartum } \\
\text { mother }\end{array}$ & $\begin{array}{l}\text { Unsupportive partner * } \\
\text { stressful life events, cesarean } \\
\text { section. }\end{array}$ & Not exposed to IPV, pregnancy planned, & $\begin{array}{l}\text { Postpartum } \\
\text { Depression }\end{array}$ \\
\hline $\begin{array}{l}\text { Yamada, et } \\
\text { al (2020) }\end{array}$ & Japan & $\begin{array}{l}\text { Cross } \\
\text { sectional }\end{array}$ & 6.195 & $\begin{array}{l}\text { Postpartum } \\
\text { mother }\end{array}$ & $\begin{array}{l}\text { Lack of social support from } \\
\text { partner / other person }{ }^{*} \text {, age } \\
<25 \text { yrs and }>40 \text { yrs, } \\
\text { unstable financial status, } \\
\text { unwanted pregnancy, }\end{array}$ & $\begin{array}{l}\text { Good family support*, spouse does not } \\
\text { use alcohol, income (> 3001-50oo RM) }\end{array}$ & $\begin{array}{l}\text { Postpartum } \\
\text { Depression }\end{array}$ \\
\hline
\end{tabular}




\begin{tabular}{|c|c|c|c|c|c|c|c|}
\hline & & & & & $\begin{array}{l}\text { unsatisfactory delivery, } \\
\text { verbal abuse from partners, } \\
\text { history of depression, history } \\
\text { of mental disorders. }\end{array}$ & & \\
\hline $\begin{array}{l}\text { Castro, et } \\
\text { al(2014) }\end{array}$ & Mexico & $\begin{array}{l}\text { Cross } \\
\text { sectional }\end{array}$ & 604 & $\begin{array}{l}\text { Postpartum } \\
\text { mother }\end{array}$ & $\begin{array}{l}\text { Age }<20 \text {, widow, low income } \\
(<\$ 2,699 \text { pesos per month }) \\
\text { weak social support *, history } \\
\text { of depression, unplanned } \\
\text { pregnancy, exposure to IPV } \\
\text { during pregnancy. }\end{array}$ & $\begin{array}{l}{ }^{*} \text { Supporting partner, no stressful life } \\
\text { events, normal delivery. }\end{array}$ & $\begin{array}{l}\text { Postpartum } \\
\text { Depression }\end{array}$ \\
\hline $\begin{array}{l}\text { Daoud, et } \\
\text { al (2019) }\end{array}$ & Canada & $\begin{array}{l}\text { Cross } \\
\text { sectional }\end{array}$ & 74.231 & $\begin{array}{l}\text { Postpartum } \\
\text { mother }\end{array}$ & $\begin{array}{l}\text { Indigenous ethnicity, 15-24 } \\
\text { years old, education }\end{array}$ & $\begin{array}{l}\text { Have social support from a partner / } \\
\text { other person *, age } 25-39 \text { years, stable } \\
\text { financial status, desired pregnancy, } \\
\text { satisfactory delivery, no verbal abuse } \\
\text { from a partner, no history of depression, } \\
\text { no history of mental disorders. }\end{array}$ & $\begin{array}{l}\text { Postpartum } \\
\text { Depression }\end{array}$ \\
\hline $\begin{array}{l}\text { Dlamini, et } \\
\text { al (2019) }\end{array}$ & Eswatini & $\begin{array}{l}\text { Cross } \\
\text { sectional }\end{array}$ & 114 & $\begin{array}{l}\text { Postpartum } \\
\text { mother }\end{array}$ & $\begin{array}{l}\text { low level, widowed / un- } \\
\text { married, use of antidepress- } \\
\text { ants before pregnancy, weak } \\
\text { social support }{ }^{*} \text {. }\end{array}$ & $\begin{array}{l}\text { Age }>20 \text {, married, income }>\$ 2,699 \\
\text { pesos per month, strong social support *, } \\
\text { no history of depression, planned } \\
\text { pregnancy, no IPV during pregnancy. }\end{array}$ & $\begin{array}{l}\text { Postpartum } \\
\text { Depression }\end{array}$ \\
\hline $\begin{array}{l}\text { Abadiga } \\
(2019)\end{array}$ & Ethiopia & $\begin{array}{l}\text { Cross } \\
\text { sectional }\end{array}$ & 295 & $\begin{array}{l}\text { Postpartum } \\
\text { mother }\end{array}$ & $\begin{array}{l}\text { Unemployment, social } \\
\text { support from partner weak } \\
\text { attending antenatal classes } \\
<4 \mathrm{x} \text {, unplanned pregnancy. }\end{array}$ & $\begin{array}{l}\text { Ethnic immigrants, age } 25-50 \text { years, } \\
\text { education }\end{array}$ & $\begin{array}{l}\text { Postpartum } \\
\text { Depression }\end{array}$ \\
\hline $\begin{array}{l}\text { Shitu, et } \\
\text { al(2019) }\end{array}$ & Ethiopia & $\begin{array}{l}\text { Cross } \\
\text { sectional }\end{array}$ & 596 & $\begin{array}{l}\text { Postpartum } \\
\text { mother }\end{array}$ & $\begin{array}{l}\text { Unplanned pregnancy, parity } \\
\text { 1, history of previous } \\
\text { depression, domestic vio- } \\
\text { lence, history of weak social } \\
\text { support substance use * }\end{array}$ & $\begin{array}{l}\text { Married, wanted pregnancy, infants } \\
\text { gender, baby is not sick, strong social } \\
\text { support * }\end{array}$ & $\begin{array}{l}\text { Postpartum } \\
\text { Depression }\end{array}$ \\
\hline $\begin{array}{l}\text { Wubetu, et } \\
\text { al (2018) }\end{array}$ & Ethiopia & $\begin{array}{l}\text { Cross } \\
\text { sectional }\end{array}$ & 308 & $\begin{array}{l}\text { Postpartum } \\
\text { mother }\end{array}$ & $\begin{array}{l}\text { Divorced / unmarried, } \\
\text { unwanted pregnancy, } \\
\text { unwanted gender, sick baby, } \\
\text { weak social support * }\end{array}$ & $\begin{array}{l}\text { Married, strong social support*, no } \\
\text { children in hospital, no family members / } \\
\text { relatives who died }\end{array}$ & $\begin{array}{l}\text { Postpartum } \\
\text { Depression }\end{array}$ \\
\hline
\end{tabular}




\section{b. Forest Plot}

Odds Ratio

Study or Subgroup log[Odds Ratio] SE Weight IV, Random, $95 \% \mathrm{Cl}$

\begin{tabular}{|c|c|c|c|c|}
\hline abadiga 2019 & 1.8856 & 0.5483 & $4.0 \%$ & $6.59[2.25,19.3$ \\
\hline ahmad 2017 & 0.5822 & 0.2392 & $12.0 \%$ & $1.79[1.12,2.8$ \\
\hline bener 2012 & 0.4187 & 0.2136 & $13.2 \%$ & $1.52[1.00,2.3$ \\
\hline castro 2014 & 1.5041 & 0.4967 & $4.7 \%$ & $4.50[1.70,11.9$ \\
\hline daoud 2019 & 0.8838 & 0.1102 & $19.0 \%$ & $2.42[1.95,3.0$ \\
\hline dlamini 2019 & 2.2418 & 0.5017 & $4.6 \%$ & $9.41[3.52,25.1$ \\
\hline nasr 2020 & 1.5107 & 0.7708 & $2.2 \%$ & $4.53[1.00,20.5$ \\
\hline shitu 2019 & 1.1506 & 0.3634 & $7.4 \%$ & $3.16[1.55,6.4$ \\
\hline wubetu 2018 & 1.6312 & 0.8323 & $1.9 \%$ & $5.11[1.00,26.1$ \\
\hline xiong 2018 & 0.7514 & 0.0751 & $20.8 \%$ & $2.12[1.83,2.4$ \\
\hline yamada 2020 & 1.9769 & 0.7202 & $2.5 \%$ & $7.22[1.76,29.6$ \\
\hline zeadna 2015 & 0.9555 & 0.3537 & $7.7 \%$ & $2.60[1.30,5.2$ \\
\hline Total $(95 \% \mathrm{Cl})$ & & & $100.0 \%$ & $2.64[2.08,3.3$ \\
\hline $\begin{array}{l}\text { Heterogeneity: } \\
\text { Test for overall }\end{array}$ & $=0.000$ & $\begin{array}{l}d f=1 \\
01)\end{array}$ & $P=0.0$ & $=55 \%$ \\
\hline
\end{tabular}

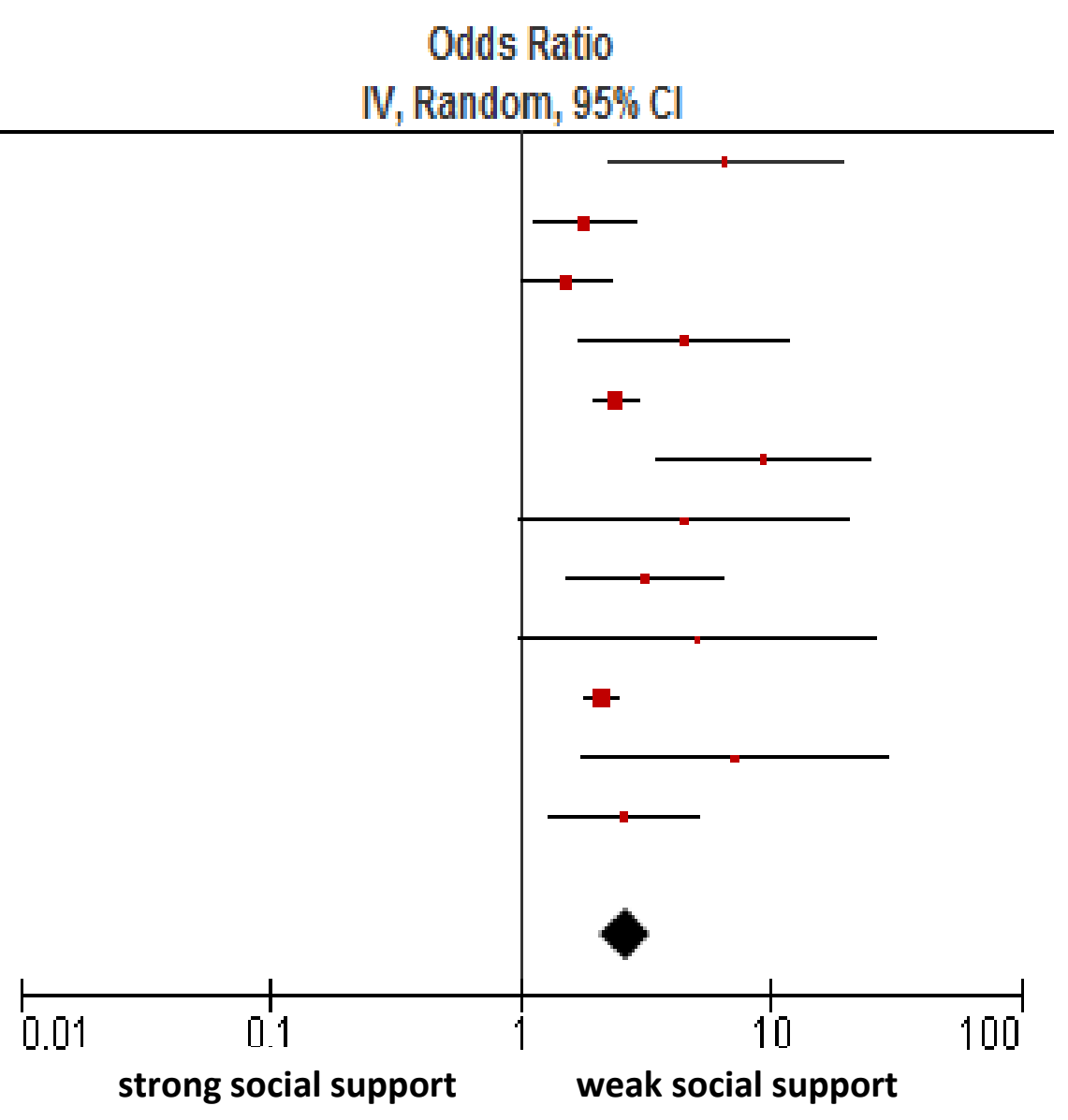

Figure 2. Forest plot of the relationship between social support and postpartum depression 


\section{c. Funnel Plot}

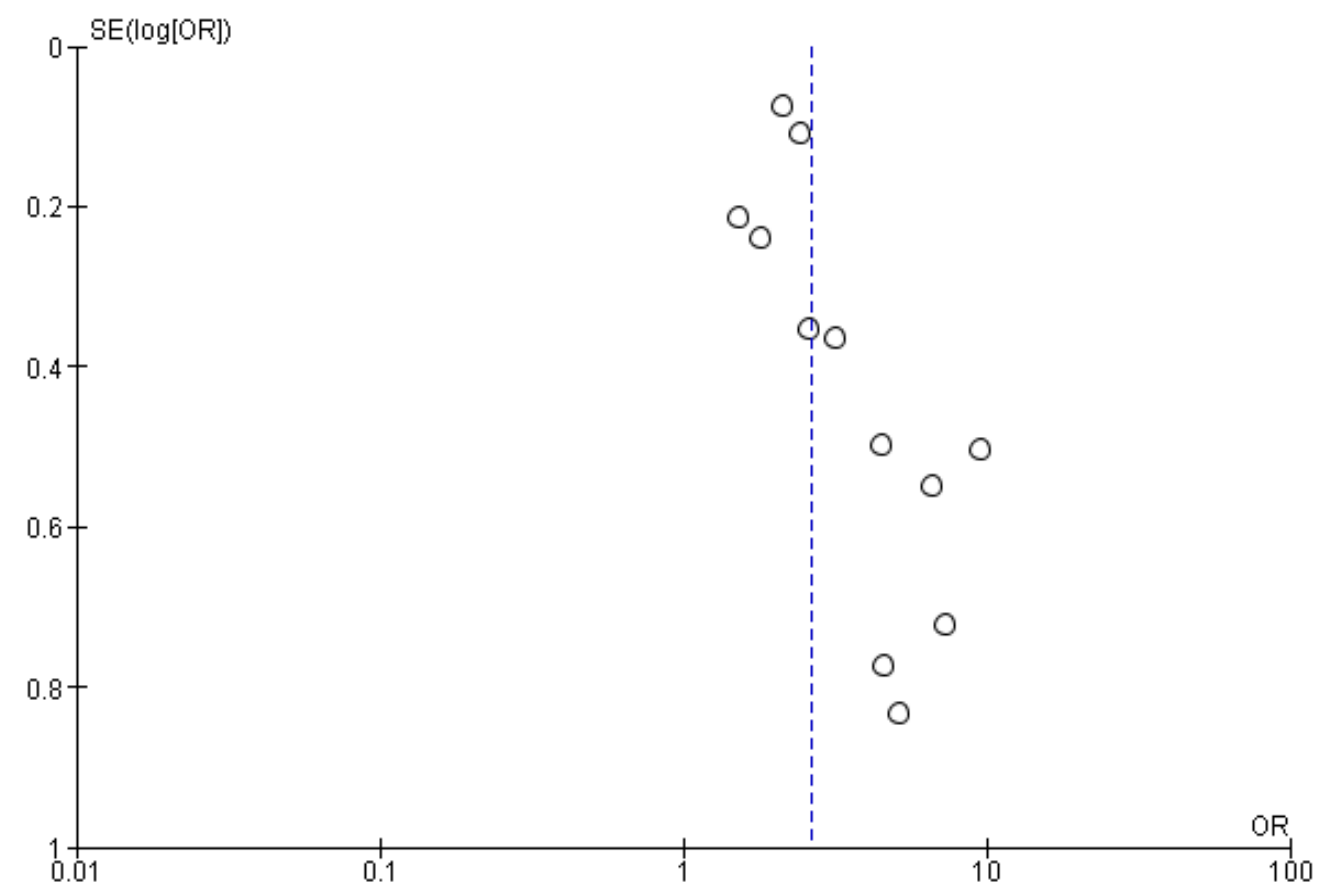

\section{Figure 3. Funnel plot of the relationship between social support and postpartum depression}

Based on the results of the forest plot in Figure 2, it shows that postpartum women who have weak social support increase the risk of postpartum depression by 2.64 times than postpartum women who have strong social support and it is statistically significant ( $\mathrm{p}<0.001)$. The heterogeneity of the research data shows $\mathrm{I}^{2}=55 \%$ so that the Forest plot display uses the Random Effect Model. The funnel plot in Figure 3 shows a publication bias which is characterized by asymmetry of the right and left plots where 7 plots are on the right and 5 plots are on the left. The plot on the left of the graph appears to have a standard error between 0 and 0.4 and the plot on the right has a standard error between 0 and o.8.

\section{DISCUSSION}

This was a systematic review and meta-analysis. The aim of this study was to estimate the strength of the relationship between social support and postpartum depression based on a number of previous primary studies. The primary research used in this study is research that has controlled confounding factors with multivariate logistic regression analysis and the results of the study are reported in the form of Adjusted Odds Ratio (aOR). Counfonding factors must be controlled because they can influence the effect of exposure to disease events and thus invalidate the study results.

The combination of various studies was processed using Revman 5.3 software. The results of the systematic study and meta-analysis are presented in the form of a forest plot and a funnel plot. The forest plot is a diagram that shows information from each of the studies examined in the metaanalysis and estimates of the overall results. The funnel plot shows the relationship between the effect size of the study and the 
sample size or standard error of the effect size of the various studies studied (Murti, 2018). A funnel plot is a diagram used to visually show possible publication bias.

Postpartum depression is a public health problem that affects maternal health and child development. This has a negative impact on the health of the mother and her ability to care for the baby. Postpartum depression can affect a mother's attachment to her baby, causing inadequate social, emotional and cognitive development of the child and can also lead to poor infant feeding practices, leading to malnutrition and sub-optimal growth of the baby.

Previous studies have found that risk factors for postpartum depression are grouped into five main groups: biological factors, including changes in hormone levels and maternal age; physical factors, including chronic health problems and antenatal depression; psychological factors, including prenatal anxiety, stress, lack of social support and a stressful life; obstetric/ pediatric factors, including unwanted pregnancy, a history of miscarriage and a severely ill baby; and socio-cultural factors, including maternal status and poverty (Giri et al., 2015).

\section{Relationship between social support and postpartum depression}

The results of a meta-analysis of 12 aggregated articles on the relationship between social support and postpartum depression are shown by the Forest plot. The forest plot in Figure 4.2 shows that postpartum mothers with weak social support have 2.64 times the risk of experiencing postpartum depression compared to mothers who have strong social support. These results were statistically significant with values $(\mathrm{aOR}=$ 2.64; 95\% CI: 2.08 to 3.35; P: 0.00001).

The results of the study are supported by several other studies which suggest that lack of social support is an important risk factor for postpartum depression, whereas the presence of social support can be a buffer against postpartum depression (Kim et al., 2014; Pilkington et al., 2015; Reid and Taylor, 2015; Li et al., 2017; Pao et al., 2019).

This study is in line with Xiong and Deng (2020) which states that mothers who receive weak social support are associated with the development of postparum depression. Abadiga (2019) says that a lack of husband or family support during a stressful perinatal period will make the woman feel helpless and prone to depression after childbirth. According to Vaezi et al (2018), social support reduces the stress of pregnancy, childbirth, and other stressful life events and increases the mother's selfconfidence.

Another study conducted by Yamada et al (2020) states that a lack of social support from a partner or other person indicates a higher risk of postpartum depression in mothers, compared to those who receive more social support from partners or other people. Postpartum mothers who did not receive social support from both their partner and other people showed a high risk of developing postpartum depression, namely 7.2 times more likely to have postpartum depression.

Social support during the perinatal period is very important. Lack of social support makes them vulnerable to stress, loneliness and hopelessness. Postpartum women who receive partner support during the puerperium will empower them to handle household responsibilities. Moreover, it is the fact that social support plays a buffer role of stressful life events by providing resources, support, and strength during the postpartum period (Shitu et al., 2019). 
Ardiani et al./ The Association between Social Support and Postpartum Depression

\section{AUTHOR CONTRIBUTION}

Ardiani is the principal researcher who selects topics, explores and collects data. RB. Soemanto and Bhisma Murti played a role in analyzing data and reviewing documents.

\section{CONFLICT OF INTEREST}

There is no conflict of interest in this study.

FUNDING AND SPONSORSHIP

This study is self-funded.

ACKNOWLEDGEMENT

We would like to thank database providers Pubmed, Google Scholar, Science Direct, and Spinger Link.

\section{REFERENCE}

Abadiga M (2019). Magnitude and associated factors of postpartum depression among women in Nekemte town, East Wollega zone, west Ethiopia, 2019: A community-based study. PloS one, 14(11): e0224792. https://doi.org/10.1371/journal.pone.0224792.

Ahmad NA, Silim UA, Rosman A, Mohamed M, Chan YY, Kasim NM, Jamaluddin R (2018). Postnatal depression and intimate partner violence: a nationwide clinic-based cross-sectional study in Malaysia. BMJ open. 8:e020649.http://dx.doi.org/10.1136 /bmjopen-2017-020649.

Bahiyatun (2010). Buku Ajar Asuhan Kebidanan Nifas Normal (Textbook of Normal Postpartum Midwifery Care). Jakarta: EGC.

Fedora I (2019). Ibu hamil dan nifas dalam ancaman depresi (pregnant and postpartum women under threats of depression). Jawa Tengah: Pena Persada.

Gomez CM, Peral PM, Bellon JA, Ceron SC, Paino HC, Gomez IG, Rigabert A,
Benitez I, Motrico E (2015). Effectiveness of psychological, psychoeducational and psychosocial interventions to prevent postpartum depression in adolescent and adult mothers: Study protocol for a systematic review and meta-analysis of randomised controlled trials. BMJ Open. o: eo34424. doi:10.1136/ bmjopen-2019-034424.

Giri RK, Khatri RB, Mishra SR, Khanal V, Sharma VD (2015). Prevalence and factors associated with depressive symptoms among post-partum mothers in Nepal. BMC Res Notes. 8: 111. https://doi.org/10.1186/s13104-0151074-3.

Kim THM, Connolly JA, Tamim H (2014). The effect of social support around pregnancy on postpartum depression among Canadian teen mothers and adult mothers in the maternity experiences survey. BMC Pregnancy Childbirth. 14: 162. https://dx.doi.org/10.1186\%2F1471-2393-14-162.

Li Y, Long Z, Cao D, Cao F (2017). Social support and depression across the perinatal period: A longitudinal study. J Clin Nurs. 26(17-18): 2776-2783. https://doi.org/10.1111/ijlh.12426

Murti B (2018). Prinsip dan Metode Riset Epidemiologi. Edisi IV. Cetakan I. Surakarta: Program Studi Ilmu Kesehatan Masyarakat, Program Pascasarjana, Universitas Sebelas Maret.

Ozbasaran F, Çoban A, Kucuk M (2011). Prevalence and risk factors concerning postpartum depression among women within early postnatal periods in Turkey. Arch Gynecol Obstet. 283 (3): 483-9o. https://doi.org/10.1007/s00404-010-1402-8.

Pao C, Guintivano J, Santos H, Meltzerbrody S (2018). Postpartum depression and social support in a racially and ethnically diverse population of 
Ardiani et al./ The Association between Social Support and Postpartum Depression

women. Arch Womens Ment Health. 22(1): 105-114. https://doi.org/10.1007/s00737-018-0882-6.

Pilkington PD, Whelan TA, Milne LC, (2016). Maternal crying and postpartum distress: the moderating role of partner support of partner support. J Reprod Infant Psy. 34(1): 64-76. https://doi.org/10.1080/02646838.2015.1067884.

Reid KM, Taylor MG (2015). Social support, stress, and maternal postpartum depression: A comparison of supportive relationships. Soc Sci Res. 54: 246-62. https://doi.org/10.1016/j.ssresearch. 2015.08.009.

Shitu S, Geda B, Dheresa M (2019). Postpartum depression and associated factors among mothers who gave birth in the last twelve months in Ankesha district, Awi zone, North West Ethiopia. BMC pregnancy and childbirth, 19(1): 435. https://doi.org/10.1186/s12884-019-2594-y.

Tambag H, Turan Z, Tolun S, Can R (2010). Social support and postpartum depression in low-socioeconomic level postpartum women in Eastern Turkey. Int J Public Health. 55(6): 543-9. https://doi.org/10.1007/s00038-010o182-z
Tani F, Castagna V, Tani F, Castagna V (2016). Maternal social support, quality of birth experience, and postpartum depression in primiparous women Maternal social support, quality of birth experience and post-partum. 7058(May). https://doi.org/10.1080/14767058.2016.1182980

Vaezi A, Soojoodi F, Tehrani A, Nojomi M (2018). The association between social support and postpartum depression in women: A cross sectional study. Women Birth. 32(2): e238-e242. https://doi.org/10.1016/j.wombi.201 8.07.014.

Yagmur Y, Ulukoca N (2010). Social support and postpartum depression in low-socioeconomic level postpartum women in Eastern Turkey. Int $\mathrm{J} \mathrm{Pu}$ blic Health. 55(6): 543-9. .https://doi.org/10.1007/s00038-010-0182-z

Yamada A, Isumi A, Fujiwara T (2020). Association between lack of social support from partner or others and postpartum depression among Japanese mothers: A population-based cross-sectional study. Int $\mathrm{J}$ Environ Res Public Health. 17(12): 4270. https://dx.doi.org/10.3390\%2Fijerph 17124270 . 